\title{
DNA barcoding of marine polychaetes species of southern Patagonian fjords
}

\author{
Barcoding de poliquetos marinos de los fiordos patagónicos del sur de Chile
}

\section{Claudia S. Maturana", Rodrigo A. Moreno ${ }^{1,2,3}$, Fabio A. Labra ${ }^{2}$, Claudio A. González- Wevar $^{1}$, Nicolás Rozbaczylo ${ }^{4}$, Franklin D. Carrasco ${ }^{5}$ and Elie Poulin ${ }^{1}$}

\author{
${ }^{1}$ Instituto de Ecología y Biodiversidad (IEB), Facultad de Ciencias, Universidad de Chile, Casilla 653, Santiago, Chile. \\ cmaturana.ciencias@gmail.com \\ ${ }^{2}$ Centro de Investigación en Ciencias Ambientales (CIENCIA-UST), Facultad de Ciencias, Universidad Santo Tomás, Ejército 146, \\ Santiago, Chile \\ ${ }^{3}$ Departamento de Ciencias Básicas, Universidad Santo Tomás, Avenida Arturo Prat 850, Concepción, Chile \\ ${ }^{4}$ Departamento de Ecología, Facultad de Ciencias Biológicas, Pontificia Universidad Católica de Chile, Casilla 114-D, Santiago, Chile \\ ${ }^{5}$ Departamento de Oceanografía, Facultad de Ciencias Naturales y Oceanográficas, Universidad de Concepción, Casilla 160-C, \\ Concepción, Chile
}

\begin{abstract}
Resumen.- La identificación de especies se establece como una de las principales etapas para cualquier estudio sobre biodiversidad, en especial frente a cambios globales y sus repercusiones. Es por esto que se requiere un amplio conocimiento taxonómico en los diferentes grupos de organismos. La herramienta de ADN barcoding ha sido descrita como una importante alternativa a los estudios morfológicos tradicionales, permitiendo complementar las técnicas de identificación en un amplio número de taxa. En este estudio, se analiza la divergencia genética intraespecífica e interespecífica entre poliquetos marinos de los fiordos patagónicos del sur de Chile, utilizando el gen Citocromo c Oxidasa Subunidad I (COI). Los resultados muestran que las 31 secuencias obtenidas de 13 especies analizadas exhiben altos niveles de variación interespecífica. La comparación intraespecífica de distancias genéticas basadas en K2P varió entre 0,2 a 0,4\% En contraste, las comparaciones interespecíficas fueron mucho mayores y variaron entre 18 a $47 \%$ con excepción de las especies congenéricas Asychis chilensis y Asychis amphiplypta, las cuales no presentaron monofilia recíproca. Este trabajo representa el primer estudio que muestra resultados mediante la herramienta de barcoding en poliquetos de la zona sur de Chile. Además establece la efectividad de esta herramienta alternativa para la identificación de especies de poliquetos marinos en los fiordos Patagónicos, y así disponerlo a la comunidad científica para sus futuras aplicaciones.
\end{abstract}

Palabras clave: Taxonomía molecular, Polychaeta, Citocromo c Oxidasa Subunidad I, CIMAR-13 Fiordos, Chile

\begin{abstract}
Accurate species identification remains a basic first step in any study of biodiversity, particularly for global changes and their consequences. Thus, there is a pressing need for taxonomic expertise in a broad range of taxa. DNA barcoding has proved to be a powerful alternative method to traditional morphological approaches, allowing to complement identification techniques for living organisms. In this study, we assess intraspecific and interspecific genetic divergence among marine polychaetes from Patagonian fj ords of southern Chile, using mitochondrial Cytochrome c Oxidase Subunit I (COI) gene. Our results showed that a total of 13 polychaetes species identified in this study exhibited high levels of interspecific variation among 31 analyzed sequences. Mean pairwise sequence distances comparisons based on K2P within species ranged from 0.2 to $0.4 \%$ In contrast, interspecific comparisons were much higher and ranged between 18 to $47 \%$ with the exception of the congeneric species Asychis chilensis and Asychis amphiglypta that showed high levels of genetic similarities and absence of reciprocal monophyly. This study presents the first information on DNA barcoding for polychaetes species in the southern Chile, and it establishes the effectiveness of DNA barcoding for identification of marine polychaetes species from Patagonian Fjords, thus making it available to a much broader range of scientists.
\end{abstract}

Key words: Molecular taxonomy, Polychaeta, Cytochrome c Oxydase Subunit I, CIMAR-13 Fjords, Chile

\section{INTRODUCTION}

Sustainable conservation of species requires, among other things, appropiate knowledge about the diversity of life at different hierarchical levels, including physiological, ecological, biogeographical, and systematic information (MacArthur 1984, Spicer \& Gaston 1999, Avise 2000,
Gaston \& Blackburn 2000, Lomolino et al. 2006). However, a basic prerequisite for all these research programmes is the successful identification and delimitation of species (Gotelli 2004, Raven 2004). While concern has been voiced over the decline of taxonomy and the number of practicing 
taxonomists (Hopkins \& Freckleton 2002, Gotelli 2004, Raven 2004), accurate species identification remains an imperative condition to investigate on biodiversity and conservation. To date, traditional taxonomy relies mostly on diagnostic morphological characters, requiring expert knowledge to identify specimens. In this regard, DNA barcoding has proved to be a useful alternative method for rapid global biodiversity assessment, providing an accurate identification system for living organisms (Hebert et al. 2003, Jia Min \& Hickey 2007, Valentini et al. 2009, Tang et al. 2010). DNA barcoding translates expert taxonomic knowledge into a widely accessible format, DNA sequences, allowing a much broader range of scientists to identify specimens (Kerr et al. 2007). This method of species identification is based on detecting sequence diversity in a single standardized DNA fragment, namely, mitochondrial Cytochrome c Oxidase Subunit I (COI) (Hebert et al. 2003). Examination of nucleotide sequence diversity of this gene allows the grouping of unknown specimens with a prioridefined taxonomic species (Monaghan et al. 2005, Vogler \& Monaghan 2006) based on the assumption that intraspecific genetic divergence is lower than the interspecific one (Hebert et al. 2003, Meyer \& Paulay 2005, Waugh 2007). This method has provided a high degree of taxonomic resolution (> 94\%) for most of the species examined across several animal groups (Hebert et al. 2003, Clare et al. 2007, Waugh 2007).

In marine organisms, such as invertebrates and macroalgae, species identification using standard taxonomic analyses can be notoriously difficult (Kelly et al. 2007). This is because these taxa often show morphologic convergence and phenotypic plasticity, resulting in taxonomic lumping or splitting of species. In particular, marine polychaetes constitute a large and diverse group of invertebrates highly diverse in terms of their morphologies and ecologies (Rouse \& Pleijel 2001, Struck et al. 2007). However, the identification of species based on morphological traits is complex due to the high levels of homoplasy (Glasby \& Alvarez 1999, Pleijel 1999, Eklöf 2010). In this regard, the use of complementary techniques such as DNA sequences may enhance taxonomic and systematic studies.

The phylogenetic relationships of polychaetes is controversial, and some studies supported the monophyly of this group (Rouse \& Fauchald 1997, but see McHugh $2000,2005)$. In this sense, while many studies have used the COI gene for evaluating explicit phylogenetic hypotheses, they have not examined the properties of DNA barcoding as a molecular tool for evaluating species identification (e.g., Nylander et al. 1999, Dahlgren et al.
2000, Struck et al. 2002, Nygren \& Sundberg 2003, Jördens et al. 2004, Nygren et al. 2005, Wiklund et al. 2005, Halanych \& Janosik 2006, Ruta et al. 2007). These studies encountered problems with the use of this gene, for example, a low phylogenetic signal for resolving closed relationship among polychaetes, and conclude that the $\mathrm{COI}$ region is not useful, when used alone, for inferring phylogenetics relationship among polychaetes. Nevertheless, in a molecular taxonomy perspective, Meyer \& Paulay (2005) have indicated that DNA barcoding holds promise for identification in taxonomically well-understood and thoroughly sampled clades. Thus, DNA barcoding should be carried out only if based on solid taxonomic foundations. In this respect, the taxonomy of marine polychaetes of the Magellanic Patagonian fjords in the southestern Pacific of the Chilean coast has recently received a particular attention (Rozbaczylo et al. 2005, 2006a, b, c). These studies represent an important improvement of species identification of a particularly rich and complex fauna. In line with Meyer \& Paulay (2005), the intensive taxonomic analyses carried out on marine polychaetes, provide an excellent opportunity to test the efficacy of barcode-based species delimitation in a particularly challenging group. DNA barcoding might be a potentially valuable method for identifying polychaetes species, making it available to a much broader range of researchers and particularly to non-specialists. The development of DNA barcoding for polychaetes is still scarce, although some studies are currently being conducted in the Scandinavian waters, as well as in the Arctic and Antarctic Oceans (see Nygren et al. 2007, Carr \& Hebert 2008, Grant \& Linse 2009). Recently, the Chilean National Oceanographic Committee (CONA) has supported a barcode initiative to assess marine biodiversity along the Chilean coast through the improvement of molecular tools for taxonomic studies in marine polychaetes. Here, we assess intraspecific and interspecific genetic divergence among marine polychaetes, using COI. Our specific goal was to test the degree of accuracy of DNA barcoding to discriminate morphological described species of marine polychaetes at different taxonomical levels.

\section{MAterials AND METHODS}

\section{SAMPLING AND IDENTIFICATION}

Polychaetes species were collected in the sublittoral softbottoms from Boca del Guafo ( $43^{\circ} 45^{\prime} \mathrm{S}$ ) to Estero Elefante (46 $28^{\circ} \mathrm{S}$ ) in the Magellanic Patagonian fjords of southern Chile. All the biological material was collected using an Agassiz Trawl ranging from 126 to $337 \mathrm{~m}$ depth during the 
CIMAR-13 Fjords Chilean research cruise. Samplings were conducted between July and August of 2007 on board R/V AGOR Vidal Gormáz (Table 1). Individual specimens were assigned to polychaetes species based on traditional morphology, following the classification of HartmannSchröder (1962, 1965), Fauchald (1977) and Rozbaczylo et al. (2005, 2006a, b, c). These taxa were grouped in clades following Rouse \& Fauchald (1997) and Rouse \& Pleijel (2001). Voucher samples from this study were deposited in «Colección de Flora y Fauna Profesor Patricio Sánchez Reyes (SSUC)», Departamento de Ecología, Pontificia Universidad Católica de Chile, Santiago, Chile.

\section{DNA ISOLATION, AMPLIFICATION AND SEQUENCING}

The 50 specimens belonging to 13 polychaetes species were preserved in 95\% ethanol for subsequent analyses and whole DNAs were extracted from soft tissues using the Extraction Kit procedure 'DNeasy Blood \& Tissue' (Qiagen). Partial fragments of the mitochondrial gene Cytochrome c Oxidase
Subunit I were amplified using universal primers described by Folmer et al. (1994). Polymerase chain reaction (PCR) amplifications were made in a $25 \mu \mathrm{L}$ of reaction volume consisted of $2.5 \mu \mathrm{L} 10 \mathrm{X}$ buffer $(50 \mathrm{mM} \mathrm{KCl}, 10 \mathrm{mM}$ Tris$\mathrm{HCl}, \mathrm{pH}$ 8.0), $1.0 \mu \mathrm{L} 50 \mathrm{mM} \mathrm{MgCl}{ }^{2}, 1 \mu \mathrm{L}(20 \mathrm{mM})$ dNTP's, $0.8 \mu \mathrm{L} 1 \mu \mathrm{g} \mu \mathrm{L}^{-1} \mathrm{BSA}, 0.5 \mu \mathrm{L}$ of each primer, $1 \mathrm{U}$ Taq polymerase (Invitrogen), $15.4 \mu \mathrm{L}$ of double-distilled water, and 30 ng of DNA. PCR cycling parameters included an initial denaturation phase at $97^{\circ} \mathrm{C}$ for $10 \mathrm{~min}$, followed by 40 cycles at $94^{\circ} \mathrm{C}$ for $1 \mathrm{~min}, 48.5^{\circ} \mathrm{C}$ for $1 \mathrm{~min}$, and $72^{\circ} \mathrm{C}$ for $2 \mathrm{~min}$, and ended with a final extension at $72^{\circ} \mathrm{C}$ for $13 \mathrm{~min}$. Amplified products were visualized in agarose gels (2\%) stained with ethidium bromide and purified using the kit Wizard $^{\circledR}$ SV gel and PCR Clean-Up system (Promega). Finally, all amplicons were automatically sequenced in both direction at Macrogen S.A. Korea (www.macrogen.com). All sequences obtained in this study have been deposited in GenBank under accession numbers JF731012-JF731024.

Table 1. Summary of taxonomic classification, number of individuals sequenced ( $N$ ), number of replicates used ( $r$ ), number of haplotypes registered for each species, sampling localities, georeferences and depth obtained for polychaetes species collected from the Patagonian fjords of southern Chile / Resumen de la clasificación taxonómica, número de individuos secuenciados (N), número de réplicas usadas por especie ( $r$ ), número de haplotipos encontrados para cada especie, localidades de muestreo, georeferenciación y profundidad de las especies de poliquetos recolectadas en los fiordos Patagónicos del sur de Chile

\begin{tabular}{|c|c|c|c|c|c|c|c|c|c|}
\hline Clade & Family & Species & $\mathrm{N}$ & $\mathrm{r}$ & Hap & Locality & Latitude & Longitude & Depth (m) \\
\hline Sabellida & Sabellariidae & $\begin{array}{l}\text { Idanthyrsus macropalea } \\
\text { Schmarda, } 1861\end{array}$ & 4 & 4 & 4 & Canal Puyuguapi & $44^{\circ} 49.40^{\prime} \mathrm{S}$ & $72^{\circ} 55.40^{\prime} \mathrm{W}$ & 270 \\
\hline \multirow[t]{6}{*}{ Terebellida } & Ampharetidae & $\begin{array}{l}\text { Melinna cristata australis } \\
\text { Hartmann-Schröder, } 1965\end{array}$ & 1 & 4 & 1 & Estero Quitralco & $45^{\circ} 39.98^{\prime} \mathrm{S}$ & $73^{\circ} 16.41^{\prime} \mathrm{W}$ & 230 \\
\hline & Pectinariidae & $\begin{array}{r}\text { Cistenides ehlersi } \\
\text { (Hessle, 1917) }\end{array}$ & 3 & 3 & 3 & $\begin{array}{l}\text { Boca Canal } \\
\text { Puyuguapi }\end{array}$ & $44^{\circ} 56.30^{\prime} \mathrm{S}$ & $73^{\circ} 16.20^{\prime} \mathrm{W}$ & 323 \\
\hline & Terebellidae & $\begin{array}{l}\text { Artacama valparaisiensis } \\
\quad \text { Rozbaczylo \& Méndez, } 1996\end{array}$ & 2 & 2 & 1 & Canal Puyuguapi & $44^{\circ} 49.40^{\prime} \mathrm{S}$ & $72^{\circ} 55.40^{\prime} \mathrm{W}$ & 270 \\
\hline & & $\begin{array}{r}\text { Thelepus plagiostoma } \\
\text { (Schmarda, 1861) }\end{array}$ & 1 & 4 & 1 & Canal Puyuguapi & $44^{\circ} 53.00^{\prime} \mathrm{S}$ & $73^{\circ} 02.10^{\prime} \mathrm{W}$ & 170 \\
\hline & Trichobranchidae & $\begin{array}{l}\text { Terebellides stroemi kerguelensis } \\
\text { McIntosh, } 1885\end{array}$ & 1 & 5 & 1 & Canal Puyuguapi & $44^{\circ} 49.40^{\prime} \mathrm{S}$ & $72^{\circ} 55.40^{\prime} \mathrm{W}$ & 270 \\
\hline & Sternaspidae & $\begin{array}{r}\text { Sternaspis scutata } \\
\text { Ranzani, } 1817\end{array}$ & 3 & 4 & 1 & Seno Aysén & $45^{\circ} 22.10^{\prime} \mathrm{S}$ & $73^{\circ} 04.20^{\prime} \mathrm{W}$ & 224 \\
\hline \multirow[t]{3}{*}{ Phyllodocida } & Lumbrineridae & $\begin{array}{l}\text { Eranno chilensis } \\
\quad \text { (Kinberg, 1865) }\end{array}$ & 4 & 4 & 3 & $\begin{array}{l}\text { Boca Canal } \\
\text { Puyuguapi }\end{array}$ & $44^{\circ} 56.30^{\prime} \mathrm{S}$ & $73^{\circ} 16.20^{\prime} \mathrm{W}$ & 323 \\
\hline & & $\begin{array}{l}\text { Ninoe chilensis } \\
\text { Kinberg, } 1865\end{array}$ & 2 & 2 & 1 & Seno Aysén & $45^{\circ} 28.10^{\prime} \mathrm{S}$ & $72^{\circ} 49.90^{\prime} \mathrm{W}$ & 126 \\
\hline & & $\begin{array}{l}\text { Ninoe leptognatha } \\
\text { Ehlers, } 1900\end{array}$ & 3 & 5 & 2 & Canal Puyuguapi & $44^{\circ} 49.40^{\prime} \mathrm{S}$ & $72^{\circ} 55.40^{\prime} \mathrm{W}$ & 270 \\
\hline Eunicida & Onuphidae & $\begin{array}{l}\text { Onuphis pseudoiridescens } \\
\text { Averincev, } 1972\end{array}$ & 1 & 4 & 1 & Paso del Medio & $45^{\circ} 22.90^{\prime} \mathrm{S}$ & $73^{\circ} 31.90^{\prime} \mathrm{W}$ & 337 \\
\hline \multirow[t]{2}{*}{ Scolecida } & Maldanidae & $\begin{array}{l}\text { Asychis chilensis } \\
\quad \text { (Hartmann-Schröder, 1965) }\end{array}$ & 3 & 3 & 2 & Seno Aysén & $45^{\circ} 19.60 ' \mathrm{~S}$ & $73^{\circ} 19.70^{\prime} \mathrm{W}$ & 218 \\
\hline & & $\begin{array}{c}\text { Asychis amphiglypta } \\
\text { (Ehlers, 1897) }\end{array}$ & 3 & 3 & 3 & Canal Costa & $45^{\circ} 30.80^{\prime} \mathrm{S}$ & $73^{\circ} 31.70^{\prime} \mathrm{W}$ & 297 \\
\hline
\end{tabular}


Table 2. Mean pairwise sequence distances comparisons based on K2P (in percentage) between the analyzed taxa / Comparación de distancias genéticas basada en K2P (en porcentaje) entre los diferentes taxa analizados

\begin{tabular}{|c|c|c|c|c|c|c|c|c|c|c|c|c|c|}
\hline Species & 1 & 2 & 3 & 4 & 5 & 6 & 7 & 8 & 9 & 10 & 11 & 12 & 13 \\
\hline 1 Artacama valparaisiensis & $* * * *$ & & & & & & & & & & & & \\
\hline 2 Cistenides ehlersi & 30 & $* * * *$ & & & & & & & & & & & \\
\hline 3 Idanthyrsus macropalea & 33 & 31 & $* * * *$ & & & & & & & & & & \\
\hline 4 Ninoe chilensis & 32 & 30 & 32 & $* * * *$ & & & & & & & & & \\
\hline 5 Ninoe leptognatha & 30 & 31 & 29 & 18 & $* * * *$ & & & & & & & & \\
\hline 6 Asychis chilensis & 35 & 36 & 30 & 29 & 31 & $* * * *$ & & & & & & & \\
\hline 7 Asychis amphiglypta & 35 & 36 & 30 & 29 & 31 & N/A & $* * * *$ & & & & & & \\
\hline 8 Eranno chilensis & 37 & 31 & 29 & 23 & 22 & 32 & 32 & $* * * *$ & & & & & \\
\hline 9 Sternaspis scutata & 41 & 43 & 44 & 42 & 41 & 47 & 47 & 40 & $* * * *$ & & & & \\
\hline 10 Melinna cristata australis & 27 & 26 & 30 & 27 & 28 & 30 & 30 & 30 & 40 & $* * * *$ & & & \\
\hline 11 Thelepus plagiostoma & 29 & 33 & 36 & 37 & 34 & 36 & 36 & 33 & 44 & 34 & $* * * *$ & & \\
\hline 12 Terebellides stroemi kerguelensis & 28 & 25 & 29 & 32 & 32 & 32 & 32 & 31 & 39 & 20 & 32 & $* * * *$ & \\
\hline 13 Onuphis pseudoiridescens & 23 & 32 & 32 & 34 & 32 & 32 & 32 & 34 & 43 & 26 & 31 & 29 & $* * * *$ \\
\hline
\end{tabular}

\section{EDITION, ALIGNMENT AND STATISTICAL ANALYSES}

COI sequences were edited with ProSeq 2.91 (Filatov 2002) and multiple alignments were done using Clustal W (Thompson et al. 1994). Following alignments, COI sequences were translated to aminoacids to check for the presence of premature stop codons that indicate the presence of nuclear pseudogenes or sequencing errors. The probability of substitutional saturation for the COI was determined statistically using DAMBE 4.5.56 (Xia \& Xie 2001). Sequence divergence was estimated using the Kimura twoparameters (K2P) model of base substitution (Kimura 1980). Phenetic reconstruction was done using a distance based method, Neighbor-Joining (NJ), carried out in MEGA4 software (Tamura et al. 2007) with the K2P model of substitution. Support for nodes in NJ analyses was assessed using non-parametric bootstrapping with 20,000 full heuristic pseudo-replicates. We only considered clusters that were supported by at least $95 \%$ (Felsenstein 1985). For comparative purposes, we used the sequence of the sipunculid Sipunculus nudus Linné, 1767 (Genbank Accession Number: EF521189.1) to root the tree.

\section{Results}

A total of 31 specimens, from 13 polychaetes species, were successfully sequenced and analyzed using a 555 bp fragment of the COI gene (Table 1). On average, sequences were adenine and thymine (A-T) rich (59.8\%) compared to mean guanine and cytocine (C-G) content (41.2\%). Polychaetes species exhibited high levels of variation among their sequences, 299 sites were variable (53.88\%) and 280 of them $(50.45 \%)$ were parsimonious informative. As expected for coding regions, no indels or stop codons were detected. Saturation tests did not detect significant levels of saturation at the third codon position. Mean pairwise sequence distances comparisons based on K2P within species ranged from 0.2 to $0.4 \%$. In contrast, interspecific comparisons were much higher and ranged between 18 to 47\% (Table 2), with the exception of the congeneric species Asychis chilensis (Hartmann-Schröder 1965) and Asychis amphiglypta (Ehlers 1897) that did not conform reciprocal monophyly (Fig. 1).

\section{Discussion}

In the seminal report describing DNA barcoding, Hebert et al. (2003) suggested that DNA-based identification founded on the mitochondrial Cytochrome c Oxidase Subunit I would serve as the core of a global bioidentification system for animal life. This line of reasoning holds that when fully developed, COI identification system will provide a reliable, cost-effective and accessible solution to the current problem of species identification, generating also new insights into the diversification of life and the rules of molecular evolution. 


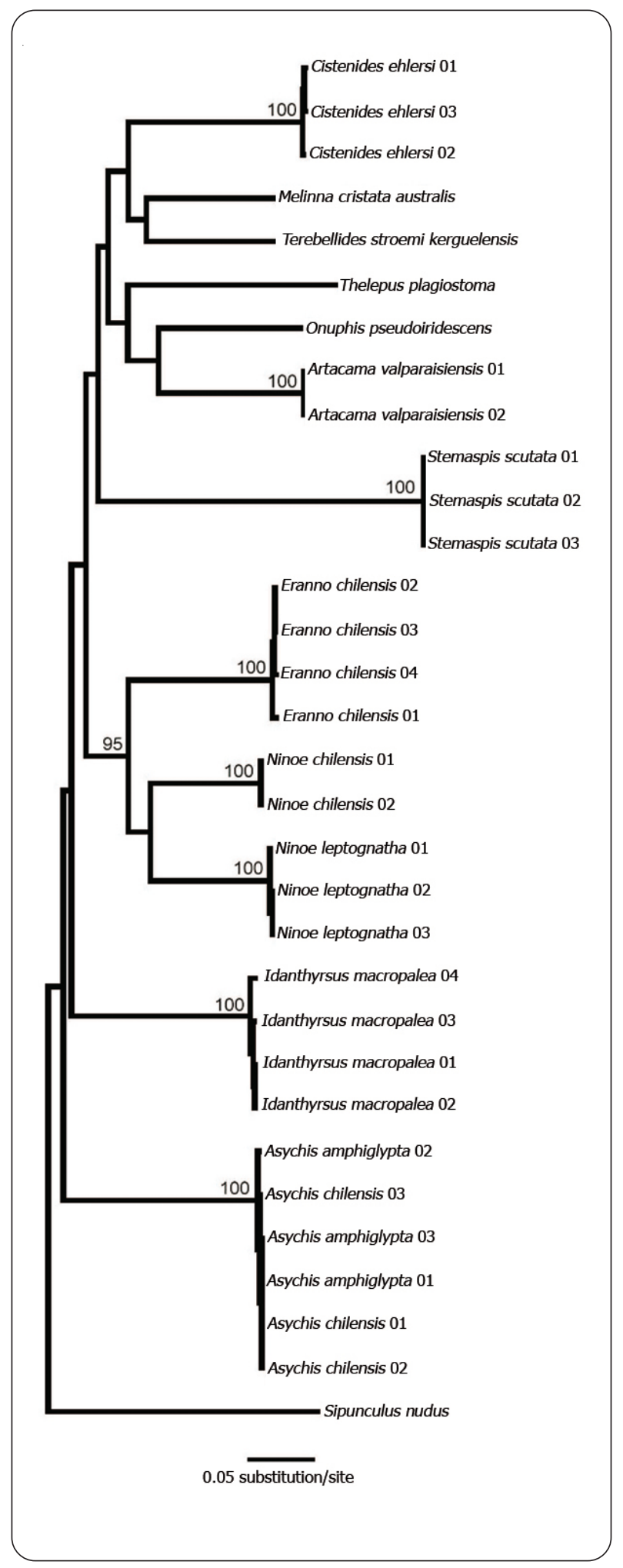

Hebert et al. (2003) proposed two principal elements in the DNA barcoding initiative. First, the ability to assign an unknown sample to a known species, and second, the ability to detect previously unsampled species as distinct. Many researchers have criticised this approach, particularly when used in a molecular systematic context. These criticisms focus mainly on the limitations of using a single-locus system to identify species and quantify global biodiversity (Stoeckle 2003, Tautz et al. 2003, Moritz \& Cicero 2004, Meyer \& Paulay 2005, Valentini et al. 2009, but see Baker et al. 2009).

Also, it is well known that identical or similar mitochondrial DNA sequences can be in different related species due to introgression or incomplete lineage sorting since the speciation event (Meyer \& Paulay 2005, Valentini et al. 2009). On the other hand, heteroplasmy, the presence of mixtures of more than one type of an organellar genome within a cell or individual can obscure the use of a single mitochondrial marker. It has also been argued that DNA barcoding may have limited phylogenetic resolution because it does not incorporate an adequate sampling of variation within species (Moritz \& Cicero 2004, Meyer \& Paulay 2005). However, barcoding used as identification tool does not suffer such criticisms. Assigning an unknown to a known element is promising especially for well-known, comprehensivelly sampled groups studied by genetic and morphological taxonomy, thus, DNA barcoding holds promise for identification in taxonomically well-understood groups (Meyer \& Paulay 2005). Given that the taxonomy and systematic of the Class Polychaeta is complex and still being developed (McHugh, 2000, 2005, Rouse \& Pleijel 2001, 2003, Bleidorn et al. 2003, Nygren \& Sundberg 2003, Halanych \& Janosik 2006, Rousset et al. 2007, Struck et al. 2007), the DNA barcoding provides undoubtedly a useful potential tool for polychaete species identification. In this regard, a series of recent studies have provided a solid understanding of the morphological taxonomy of marine polychaetes found along the south eastern Pacific, particularly in the Chilean Magellanic Patagonian fjords (Rozbaczylo et al. 2005, 2006a, b, c). These contributions represent an important improvement of available criteria for taxonomic species identification, allowing us to test the effectiveness of DNA barcoding method for marine polychaetes in this area.

Figure 1. Neighbor-joining tree analysis of the COI sequences (K2P) for 13 polychaetes species from the Patagonian Fjords of southern Chile. Only non-parametric bootstraps values $\geq \mathbf{9 5} \%$ from $\mathbf{2 0 , 0 0 0}$ iterations are shown / Análisis de neighbor-joining (K2P) utilizando las secuencias de COI de 13 especies de poliquetos obtenidos en los fiordos Patagónicos del sur de Chile. Se muestran sólo los valores de bootstrap $\geq 95 \%$ obtenidos a partir de 20.000 iteraciones 
The results obtained in this study support the effectiveness of DNA barcoding for identification of intraspecific and interspecific genetic divergence among marine polychaetes, like in Phragmatopoma spp. (Drake et al. 2007), and agreement with the values reported for other animal taxa (see Waugh 2007). Thus, the DNA barcoding method effectively discriminates the two species within the genus Ninoe with $18 \%$ of mean pairwise sequence distances (see Table 2 and Fig. 1). However, it was not able to discriminate two congeneric species of the genus Asychis. In this respect, it is interesting to note that the two species studied within the genus Asychis (A. chilensis and A. amphiglypta) do not present strong morphological differences. The diagnostic character between these nominal species is that the cephalic plate in A. chilensis is bilobulate, while in A. amphiglypta is oblique (Hartmann-Schröder 1965). Thus, a deeper understanding of the morphological taxonomy with the development of the molecular taxonomy in this genus is required for future application of barcoding.

This study has showed the first data of DNA barcoding in marine polychaetes from Magellanic Patagonian Fjords, and we have established the effectiveness of DNA barcode for polychaetes species identification in the southern of Chile, making it available to a much broader range of scientists, with possibilities to extendend to marine polychaetes in other biogeographic provinces of the southeastern Pacific Ocean (see Grant \& Linse 2009 for Antarctica). The degree of taxonomic resolution in the studied species is comparable to the results in other marine and terrestrial taxa, such as nematodes (Bhadury et al. 2006), marine hydroids (Moura et al. 2008), bivalves (Mikkelsen et al. 2007), stomatopod larvae (Tang et al. 2010), echinoderms (Ward et al. 2008), marine and fresh-water fishes (Ward et al. 2005, Ardura et al. 2010), birds (Hebert et al. 2004) and bats (Clare et al. 2007). Despite its methodological shortcomings and limitations, DNA barcoding studies have reinvigorated the development of systematic studies and taxonomic inventories around the world. The increased development of molecular systematics and taxonomy provide exciting opportunities to enrich our understanding of ancient and widespread taxa such as marine polychaetes, and support the initiatives for conserving global biodiversity.

\section{Acknowledgments}

We thank Angie Díaz, Cristián E. Hernández, Christián Ibáñez, Cecilia Pardo-Gandarillas, Pilar Salinas, Pamela Vásquez-Yañez and David Véliz for their logistic assistance during the laboratory work. Rodrigo A. Moreno and Claudio González-Wevar were supported by CONICYT Doctoral fellowships. Elie Poulin thanks the Basal Grant PFB 023, CONICYT, Chile and Iniciativa Científica Milenio Grant ICM P05-002. This study was partially funded by Servicio Hidrográfico y Oceanográfico de la Armada de Chile and Comité Oceanográfico Nacional, Grant CONA-C13F 0707.

\section{LITERATURE CITED}

Ardura A, AR Linde, JC Moreira \& E Garcia-Vazquez. 2010. DNA barcoding for conservation and management of Amazonian commercial fish. Biological Conservation 143: 1438-1443.

Avise J. 2000. Phylogeography: the history and formation of species, 464 pp. President and Fellows of Harvard College, Harvard.

Baker AJ, E Sendra-Tavares \& RF Elbourne. 2009. Countering criticisms of single mitochondrial DNA gene barcoding in birds. Molecular Ecology Resources 9 (Suppl. 1): 257-268.

Bhadury P, MC Austen, DT Bilton, PJD Lambshead, AD Rogers \& GR Smerdon. 2006. Development and evaluation of a DNA-barcoding approach for the rapid identification of nematodes. Marine Ecology Progress Series 320: 1-9.

Bleidorn C, L Vogt \& T Bartolomaeus. 2003. New Insights into polychaete phylogeny (Annelida) inferred from $18 \mathrm{~S}$ rDNA sequences. Molecular Phylogenetics and Evolution 29: 279-288.

Clare EL, BK Lim, MD Engstrom, JL Eger \& PDN Hebert. 2007. DNA barcoding of neotropical bats: species identification and discovery within Guyana. Molecular Ecology Notes 7: 184-190.

Dahlgren TG, J Lundberg, F Pleijel \& P Sundberg. 2000. Morphological and molecular evidence of the phylogeny of Nereidiform polychaetes (Annelida). Journal of Zoological Systematics and Evolutionary Research 38: 249254.

Drake CA, DA McCarthy \& CD von Dohlen. 2007. Molecular relationships and the species divergence among Phragmatopoma spp. (Polychaeta: Sabellaridae) in the Americas. Marine Biology 150: 345-358.

Eklöf J. 2010. Taxonomy and phylogeny of polychaetes, 33 pp. Intellecta Infolog, Göteborg.

Fauchald K. 1977. The polychaete worms. Definitions and keys to orders, families and genera. Natural History Museum Los Angeles County, Sciences Series 28: 1-188.

Felsenstein J. 1985. Confidence limits on phylogenies: an approach using the bootstrap. Evolution 39: 783-791.

Filatov DA. 2002. ProSeq: a software for preparation and evolutionary analysis of DNA sequence data sets. Molecular Ecology Notes 2: 621-624. 
Folmer M, M Black, W Hoeh, R Lutz \& R Vrijenhoek. 1994. DNA primers for amplification of mitochondrial cytochrome c oxidase subunit I from diverse metazoan invertebrates. Molecular Marine Biology and Biotechnology 3: 294-299.

Gaston KJ \& T Blackburn. 2000. Pattern and process in macroecology, 377 pp. Blackwell Science, London.

Glasby CJ \& B Alvarez. 1999. Distribution pattern and biogeographic analysis of Austral Polychaeta (Annelida). Journal of Biogeography 26: 507-533.

Gotelli NJ. 2004. A taxonomic wish-list for community ecology. Philosophical Transaction of the Royal Society B 359: 585-597.

Grant RA \& K Linse. 2009. Barcoding Antarctic biodiversity: current status and the CAML initiative, a case study of marine invertebrates. Polar Biology 32: 1629-1637.

Halanych KM \& AM Janosik. 2006. A review of molecular markers used for Annelid phylogenetics. Integrative and Comparative Biology 46: 533-543.

Hartmann-Schröder G. 1962. Zur Kenntnis des Eulitorals der chilenischen Pazifikküste und der argentinischen Küste Südpatagoniens unter besonderer Berücksichtigung der Polychaeten und Ostracoden. Tl. II. Die Polychaeten des Eulitorals. Mitteilungen Hamburgischen Zoologischen Museum und Institut 60 (Suppl.): 57-167.

Hartmann-Schröder G. 1965. Zur Kenntnis des Sublitorals der chilenischen Küste unter besonderer Berücksichtigung der Polychaeten und Ostracoden. Tl. II. Die Polychaeten des Sublitorals. Mitteilungen Hamburgischen Zoologischen Museum und Institut 62 (Suppl): 59-305.

Hebert PDN, A Cywinska, SL Ball \& JR de Waard. 2003. Biological identifications through DNA barcodes. Proceedings of the Royal Society of London B 270: 313321.

Hebert PDN, MY Stoeckle, TS Zemlak \& CH Francis. 2004. Identification of birds through DNA barcodes. PLOS Biology 2: 1657-1663.

Hopkins GW \& RP Freckleton. 2002. Declines in the numbers of amateur and professional taxonomists: implications for conservation. Animal Conservation 5: 245249.

Jia-Min X \& DA Hickey. 2007. Assessing the effect of varying sequence length on DNA barcoding of fungi. Molecular Ecology Notes 7: 365-373.

Jördens J, T Struck \& G Purschke. 2004. Phylogenetic inference regarding Parergodrilidae and Hrabeiella periglandulata ('Polychaeta', Annelida) based on $18 \mathrm{~S}$ rDNA, 28S rDNA and COI sequences. Journal of Zoological Systematics and Evolutionary Research 42: 270280.

Kelly RP, IN Sarkar, DJ Eernisse \& R De Salle. 2007. DNA barcoding using chitons (genus Mopalia). Molecular Ecology Notes 7: 177-183.
Kerr KC, MY Stoeckle, CJ Dove, LA Weigt, CM Francis \& PDN Hebert. 2007. Comprehensive DNA barcode coverage of North American birds. Molecular Ecology Notes 7: 535-543.

Kimura M. 1980. A simple method for estimating evolutionary rate of base substitutions through comparative studies of nucleotide sequences. Journal of Molecular Evolution 16: 111-120.

Lomolino MV, BR Riddle \& JH Brown. 2006. Biogeography, 845 pp. Sinauer Associates, Sunderland.

MacArthur RA. 1984. Geographical ecology: patterns in the distribution of species. 752 pp. Princeton University Press, Princeton

McHugh D. 2000. Molecular phylogeny of the Annelida. Canadian Journal of Zoology 78: 1873-1884.

McHugh D. 2005. Molecular systematics of polychaetes (Annelida). Hydrobiologia 535/536: 308-318.

Meyer CP \& G Paulay. 2005. DNA barcoding: error rates based on comprehensive sampling. PLOS Biology 3: 22292238.

Mikkelsen NT, C Schander \& E Willasen. 2007. Local scale DNA barcoding of bivalves (Mollusca): a case study. Zoological Scripta 36: 455-463.

Monaghan MT, M Balke, T Ryan-Gregory \& AP Vogler. 2005. DNA-based species delineation in tropical beetles using mitochondrial and nuclear markers. Philosophical Transactions of the Royal Society B 360: 1925-1933.

Moritz C \& C Cicero. 2004. DNA barcoding: promise and pitfalls. PLOS Biology 2(10): 1529-1531.

Moura CJ, DJ Harris, MR Cunha \& AD Rogers. 2008. DNA barcoding reveals cryptic diversity in marine hydroids (Cnidaria, Hydrozoa) from coastal and deep-sea environments. Zoological Scripta 37: 93-108.

Nylander JAA, C Erséus \& M Källersjö. 1999. A test of the monophyly of the gutless Phallodrilinae (Oligochaeta, Tubificidae) and the use of a 573-bp region of the mitochondrial cytocrome oxidase I gene in analysis of annelid phylogeny. Zoologica Scripta 28: 305-313.

Nygren A \& P Sundberg. 2003. Phylogeny and evolution of reproductive modes in Autolytinae (Syllidae, Annelida). Molecular Phylogenetics and Evolution 29: 235-249.

Nygren A, F Pleijel \& P Sundberg. 2005. Genetic relationships between Nereimyra punctata and $N$. woodsholea (Hesionidae, Polychaeta). Journal of Zoological Systematics and Evolutionary Research 43: 273276.

Pleijel F. 1999. Phylogenetic taxonomy, a farewell to species, and a revision of Heteropodarke (Hesionidae, Polychaete, Annelida). Systematic Biology 48(4): 755-789.

Raven PH. 2004. Taxonomy: where are we now? Philosophical Transactions of the Royal Society B 359: 729-730. 
Rouse GW \& K Fauchald. 1997. Cladistics and polychaetes. Zoologica Scripta 26(2): 139-204

Rouse GW \& F Pleijel. 2001. Polychaetes, 354 pp. Oxford University Press, Oxford.

Rouse GW \& F Pleijel. 2003. Problems in polychaete systematics. Hydrobiologia 496: 175-189.

Rousset V, F Pleijel, GW Rouse, C Erséus \& M Siddall. 2007. A molecular phylogeny of annelids. Cladistics 23: 41-63.

Rozbaczylo N, RA Moreno \& O Díaz-Díaz. 2005. Poliquetos bentónicos submareales de fondos blandos de la región de Aysén, Chile: Clado Phyllodocida (Annelida, Polychaeta). Investigaciones Marinas 33: 69-89.

Rozbaczylo N, RA Moreno \& O Díaz-Díaz. 2006a. Poliquetos bentónicos submareales de fondos blandos de la región de Aysén, Chile: Clados Amphinomida, Eunicida, Spionida, Sabellida y Scolecida (Annelida, Polychaeta). Investigaciones Marinas 34: 43-62.

Rozbaczylo N, RA Moreno \& MJ Montes. 2006b. Poliquetos bentónicos submareales de fondos blandos desde el seno Reloncaví hasta boca del Guafo, Chile (Annelida, Polychaeta). Ciencia y Tecnología del Mar 29: 95-106.

Rozbaczylo N, RA Moreno, O Díaz-Díaz \& S Martínez. 2006c. Poliquetos bentónicos submareales de fondos blandos de la región de Aysén, Chile: Clado Terebellida (Annelida, Polychaeta). Ciencia y Tecnología del Mar 29: 71-90.

Ruta C, A Nygren, V Rousset, P Sundberg, A Tillier, H Wiklund \& F Pleijel. 2007. Phylogeny of Hesionidae (Aciculata, Polychaeta), assessed from morphology, 18S rDNA, 28S rDNA, 16S rDNA and COI. Zoologica Scripta 36: 99-107.

Spicer JI \& KJ Gaston. 1999. Physiological diversity and its ecological implications, 241 pp. Blackwell Science, London.

Stoeckle M. 2003. Taxonomy, DNA, and the bar code of life. Bioscience 53(9): 2-3.

Struck T, R Hessling \& G Purschke. 2002. The phylogenetic position of the Aeolosomatidae and Parergodrilidae, two enigmatic oligochaete-like taxa of 'Polychaeta', based on molecular data from $18 \mathrm{~S}$ rDNA sequences. Journal of Zoological Systematics and Evolutionary Research 40: 155163.
Struck T, N Schult, T Kusen, E Hickman, C Bleidorn, D McHugh \& K Halanych. 2007. Annelid phylogeny and the status of sipuncula and Echiura. BMC Evolutionary Biology 7: 57-67.

Tamura K, J Dudley, M Nei \& S Kumar. 2007. MEGA4: Molecular Evolutionary Genetics Analysis (MEGA) software version 4.0. Molecular Biology and Evolution 24: 1596-1599.

Tang RWK, C Yau \& Ng W-C. 2010. Identification of stomatopod larvae (Crustacea: Stomatopoda) from Hong Kong waters using DNA barcodes. Molecular Ecology Resources 10: 439-448.

Tautz D, P Arctander, A Minelli, R Thomas \& AP Vogler. 2003. A plea for DNA taxonomy. Trends in Ecology and Evolution 18: 70-74.

Thompson JD, DG Higgins \& TJ Gibson. 1994. Clustal W: improving the sensitivity of progressive multiple sequence alignment through sequence weighting, position-specific gap penalties and weight matrix choice. Nucleic Acids Research 22: 4673-4680.

Valentini A, F Pompanon \& P Taberlet. 2009. DNA barcoding for ecologist. Trends in Ecology and Evolution 24: 110-117.

Vogler AP \& MT Monaghan. 2006. Recent advances in DNA taxonomy. Journal of Zoological Systematics Evolutionary Research 45: 1-10.

Ward RD, TS Zemlak, HI Bronwyn, PR Last, PDN Hebert. 2005. DNA barcoding Australia's fish species. Philosophical Transaction of the Royal Society B 360: 1847-1857.

Ward RD, BH Holmes \& TD O’Hara. 2008. DNA barcoding discriminates echinoderm species. Molecular Ecology Resources 8: 1202-1211.

Waugh J. 2007. DNA barcoding in animal species: progress, potential and pitfalls BioEssays 29: 188-197.

Wiklund H, A Nygren, F Pleijel \& P Sundberg. 2005. Phylogeny of Aphroditiformia (Polychaeta) based on molecular and morphological data. Molecular Phylogenetics and Evolution 37: 494-502.

Xia X \& Z Xie. 2001. DAMBE: Data analysis in molecular biology and evolution. Journal Heredity 92: 371-373.

Received 28 September 2010 and accepted 25 J anuary 2011 